\title{
DETERMINING THE RECOVERY RATE OF DICHINAMA MARBLE (LIDGE MARIAM) QUARRY SITE AT NORTHWESTERN ZONE, TIGRAI, ETHIOPIA
}

\author{
Yemane Kide Hailemariam \\ Department of Mining Engineering \\ Indian Institute of Technology (ISM) Dhanbad \\ Dhanbad, Jharkhand, India
}

\author{
Yewuhalashet Fissha, Angesom Gebretsadik \\ Department of Mining Engineering \\ Indian Institute of Technology (ISM) Dhanbad \\ Dhanbad, Jharkhand, India
}

\begin{abstract}
Marble Quarrying is the most challenging operation from the Dimensional stone Quarry Categories. It is highly affected by geological discontinuities which affects the quality of the Marble blocks such as, micro and macro fractures, joints, cavities, mudstones, and contact zones). In this study a total 135 samples of primary volume cut and its recovered volume cut were collected from the Marble Quarry site and from geology and quality control service officer of the Saba Dimensional Stone PLC to determine the recovery rate (percentage) of the Dichinama (Lidge Mariam) Quarry Site and a statistical software of SPSS version 20 were used to show the result of the recovery percentage of the Quarry site. The recoverable percentage in this study is calculated in bench wise and also as total of the Marble Quarry site as a result recovery rate from the four benches and overburden cuttings are; in the first bench $25.84 \%$, second bench $38.93 \%$, third bench $31.97 \%$, fourth bench $52.96 \%$, and from the overburden $23.49 \%$ and the total recovery rate of the Marble Quarry site is $35.72 \%$. The resulted recovery rate becomes a handy tool for Mining Engineers to work out plan for production schedule to the next before the actual Quarry operation is presented.
\end{abstract}

Keywords - Dimensional Stone, Marble, Quarrying, Recovery Rate

\section{INTRODUCTION}

The distribution of Dimensional stones found in Tigray (Mai Daro, Filafil, Nohal Ebini, Adi Hatsiro, Enda Tikurir, Newi, Akmara, and Dichinama), Gojam (Bulen, Mora, Mankush, and Baruda), Harar (Hula Kuni, Chercher mountain area); Wellega (Dalleti, Koncho) (Tadesse, Milesi and Deschamps, 2003).
One of the biggest companies which produces marble is Saba Dimensional Stone PLC Dichinama marble (Adiabo marble) is one of the biggest sites with two separate sites Lidge Mariam and Elawedizeray. Saba Dimensional Stones PLC was established in 1986 E.C. after the down fall of Derg regime and Saba has been working on the dimensional stones sector for about two and half decades involving in the quarrying and processing of Marble, Granite and Limestone Stones. It was opened by the EFFORT (Endowment fund for the rehabilitation of Tigray) members of Tigray solder. The main objective of Saba Dimensional Stone PLC is to conduct geological study throughout the region of Tigray and determine the occurrence of marble, granite, limestone, slate and other dimensional stones used for construction purpose; carry out detail geological study and feasibility study on the economic attractive areas and implement quarry operation activities according to their priorities, Produce blocks of international standard, introduce new technology for the extraction and processing of dimensional stones, penetrate in the world market and take a significant share from the international dimensional stones market and generate revenue for the progress of dimensional stone industry and in general sense the sector contribute to the economic and social development of the region. Based on the detailed geological report quarry operation activities are under progress in Adiabo marble (Dichinama), Togogo limestone, Adigolagul black marble, Adieleni gray granite and Granite blocks have been extracted from Embamadre to run the operation effectively and efficiently a system has to be developed.

\subsection{Location and Site}

Dichnama quarry (Marble Mining) is located in northern Ethiopia Tigray region Northwestern zone 


\section{International Journal of Engineering Applied Sciences and Technology, 2020 \\ Vol. 5, Issue 5, ISSN No. 2455-2143, Pages 166-183 \\ Published Online September 2020 in IJEAST (http://www.ijeast.com)}

$35 \mathrm{~km}$ far from the Sheraro town to the residence camp and $38 \mathrm{~km}$ to the active site lidge Mariam.

\subsection{Climatic Conditions}

The area is characterized by hot tropical climate. The main rainy season starts from mid-June to midSeptember and an intermittent rain during March. Temperature reaches up to 40 degree centigrade in the dry season and 30 degree centigrade in the rainy season.

\subsection{Population}

The inhabitants of the area are mainly Tigrigna speaking Tigrean people which is governed by the availability of infrastructure, grazing and cultivating lands. The subsistence of the people depends mainly on rain-fed agriculture and small-scale animal grazing.

\subsection{Power Source}

Although, electric light is not yet giving service, instead generators are used.

\subsection{Availability of Water}

Water supply for the Quarrying of marble uses underground water there is no water river in the area.

\subsection{Communication Infrastructure}

Dichinama Marble (Lidge Mariam) Site has its own wireless telephone on Dichinama residential camp, and in addition Dichinama village rendering wireless telephone service. Mobile telephone network is also available at some spots close to the camp site.

\subsection{Geology of the Area}

\subsubsection{Regional Geology}

The regional geology of Tigray comprises of the basement complex rocks which are Precambrian Meta volcanic (amphibolite's, chlorite schist, green stones etc.) and Precambrian Meta sediments (quartzite's, phyllites, slate, marble etc.) The Precambrian Meta volcanic sediments and granitoids are good source of dimensional stones(Tadesse, Milesi and Deschamps, 2003).

1.7.2 Local Geology

The local geology of the areas is Meta sediments exposures younger Sheraro formation. The marble belts of lidge Mariam marble deposits are covered with Meta sediments. That is marble bounded by chloritic and phyllitic schists.

The lidge deposit consists folded and ridge topography oriented with foliation and lithological contact in the surrounding rocks dipping to the NW at $60^{\circ}$ to the vertical and marble belt trends $N 40^{\circ} \mathrm{E}$.
Therefore, the study area found in Dichinama is covered by different degree of weathering and alterations each Metamorphic unit have its own color, Metamorphic structure and degree of weathering and alterations. Some of the Metamorphic units that exposed in the study area are Meta-sediment which is at the eastern part and western areas.

Generally, the lithology's found in the study area are listed below from oldest to youngest. These are:

- Meta volcanic and Meta volcanic clast

- Slate rock unit

- Phyllite rock unit

- Schist rock unit

- Marble rock unit

- Quartzite rock unit

The lidge Mariam marble deposit has different types of colors. These are multicolor, rose green, and white. These different color marbles have their own specific gravities.

Multicolor marble: the colored marble at lidge site varieties are usually due to various mineral impurities such as clay, silt, sand, iron oxide which are originally present as grains or layers in the limestone. This multicolor marble is expensive than others.

Rose green marble: the green coloration is often due to the serpentine and chlorite resulting from originally magnesium limestone or dolostone with silica impurities. These various impurities have been mobilized and recrystallized by the intense pressure and heat of metamorphism.

White color marble: pure white marble is the result of metamorphism of very pure limestone. It is sometimes found in lidge Mariam site.

\subsubsection{Geological Structure}

In the study area of Dichinama (Lidge Mariam) Quarry site found in the northwestern zone it has so many geological discontinuities these can be grouped in to two these are lithological and structural discontinuities. In the lithological the marble and the host rock creates the discontinuities whereas structurally the major and the minor structures contribute to affect the quality of the marble. The quality of the marble is highly affected by the minor structures.

The minor geological structures which can affect the quality of marble are;

\section{Fractures (macro and micro fractures)}

2. Joints

3. Foliation lines

4. Mudstone 


\section{International Journal of Engineering Applied Sciences and Technology, 2020 \\ Vol. 5, Issue 5, ISSN No. 2455-2143, Pages 166-183 \\ Published Online September 2020 in IJEAST (http://www.ijeast.com)}

\section{Major structure}

In the study area of Dichinama (Lidge Mariam) Quarry site the major geological discontinuity of structure is fold which lied from north to south direction.

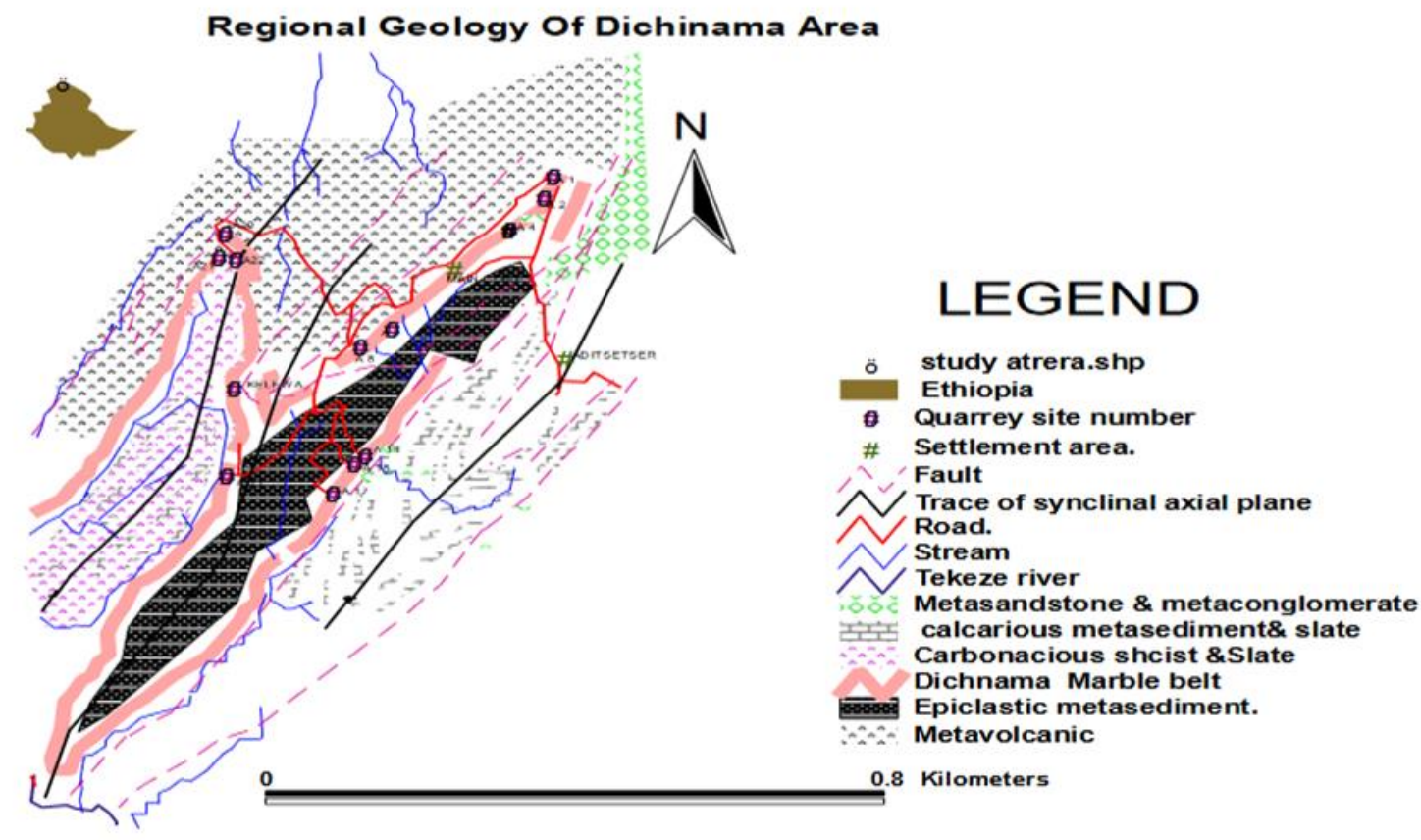

Fig. 1. Geological Map of Dichinama Marble (Lidge Mariam) Quarry Site

\subsection{Statement of the Problem}

In this study of Dichinama marble (lidge mariam) quarry site of saba dimensional stone plc. Under Quarry Operation Department Head which is geology and quality control service there is a knowledge gap of the total volume cut from primaries and total volume recovered from primaries in the actual operational work of the marble Quarrying and the plan to be cut for the next operational work of the marble Quarrying.

\subsection{Objective of the Study}

\subsubsection{General Objective}

To Determine the recovery rate of Dichinama Marble (Lidge Mariam) quarry site.

\subsubsection{Specific Objective}

To achieve the above-mentioned objective the following specific objectives were used:

$>$ To identify factors affecting the quality of Marble Quarrying
$>$ To identify the Steps of Marble Quarry operational methods

$>$ To determine the size of the Squared Blocks

$>$ To calculate the recovery rate Marble Quarrying

\section{LITERATURE REVIEW}

\subsection{Occurrence of Marble in Ethiopia}

According to Tadesse, Milesi and Deschamps (2003) some of the most interesting deposit is found in Tigray (Mai Daro, Filafil, Nohal Ebini, Adi Hatsiro, Enda Tikurir, Newi, Akmara, and Dichinama), Gojam (Bulen, Mora, Mankush, and Baruda), Harar (Hula Kuni, Chercher mountain area); Wellega (Dalleti, Koncho).

In Ethiopia, the modern and systematic mineral exploration started in 1968 with the establishment of the Ethiopian Geological Survey as a department within the Ministry of Mines and Energy. The mining sector has been able to attract private investment since the change in policy of the 


\section{International Journal of Engineering Applied Sciences and Technology, 2020 \\ Vol. 5, Issue 5, ISSN No. 2455-2143, Pages 166-183 \\ Published Online September 2020 in IJEAST (http://www.ijeast.com)}

government. Taking into consideration the current trend of private investment (Melka, 2010), the extractive sector will be one of the major revenues generating sectors in Ethiopia.

\subsection{Geological Structures of Marble Quarrying}

According to Ashmole and Motloung (2008) the following defects which affect the quality and exploitability of a dimension stone deposit:

- Colour variations

- Textural characteristics and textural variation

- Structural and macro-discontinuities

- Micro-discontinuities

- Intrusives

- Inclusions

- Accessory minerals

- Contact zones

- Alterations

Dimension stone deposits contain intact rocks and discontinuity networks (Yarahmadi et al., 2018), with joints being the most important discontinuities, Microcracks, partings, cracks, fissures, bedding planes, joints, shear zones, and faults constitute the important discontinuities which can be found in the rock mass.

The most important factors for classifying the stone blocks extracted from a quarry include discontinuities and block shape (Yarahmadi et al., 2018, 2019), especially joints filled with loose materials are the most prominent discontinuities in stone blocks.

\subsection{Marble Quarrying Operational Method}

Block production in such quarries are achieved either by way of drilling and pre-split blasting or by use of diamond wire saw cutting technology. Block production using pre-split blasting induces a number of microfractures resulting into irregular block sizes (Rajpurohit et al., 2018), thereby reducing the overall output of the quarry. This also results in poor block recovery and increased wastage leading to poor mine economics affecting the overall project operation. Diamond wire saw cutting technology is an excellent alternative to blasting and has a significant role in environment friendly and sustainable mining practices. Though the cost of cutting blocks using diamond wire saw is higher as compared to drilling and blasting, its cost is offset by savings in terms of block dressing, improved haulage efficiency, reduction of wastage, and improvement of block recovery.

According to Ozcelik, 1999; Polat, 2002; Özçelik $(2003,2005)$ there are several methods in marble block production depending on bedding condition of marble and rock properties. Nowadays, diamond wire cutting is a widely used method in marble block production. In diamond wire cutting, the cutting action primarily involves the pulling of continuous loops of spinning wire mounted with diamond bonded steel beads through the stone. In cutting operations, firstly the horizontal cutting is performed for avoiding the gravity effect of block. Then, vertical cuttings are performed. The diamond wire cutting machine is mounted on temporary track, along which it reverses to maintain tension in the wire as it cuts through the stone. Water is applied with the spin direction of the wire as a coolant and as a means of removing the particles of stone.

According to Servet et al. (2014) in marble quarries, although the heights of the benches may be up to 6$7 \mathrm{~m}$ in safety limits, $5 \mathrm{~m}$ hole lengths were considered in this study. It was seen that, although physical and mechanical rock properties are more effective in vertical than horizontal drilling, vertical stress and Poisson's ratio are more effective in horizontal than vertical drilling.

The modern two-stage high-bench marble cutting technology became applicable with availability of diamond-wire saw allowing stone cutting in wider range of linear parameters. Since natural jointing is a naturally set factor, it is only possible to change the marketable stone yield by means of linear parameters of cut stone. There are a number of procedures developed to calculate and select rational parameters of stone blocks depending on natural jointing (Pershin and Ulyakov, 2015).

Currently mining machines with flexible cutting tools prevail in stone quarrying. This is connected with their ability to cut large blocks (over $500 \mathrm{~m}^{3}$ ) to conform with higher yield of large marketable stone blocks in jointy rock masses. The use of diamond wire saws allows cutting high strength natural stone (of the type of granite). Development and application of diamond wire saws instead of abrasive wire saws, where quartz sand with water was used as an abrasive slurry, enhanced cutting capacity ten times and higher in medium strength rocks and expanded the range of the stone strength to the level of granites, dolerites, etc. Cutting of large size stones supposes high-bench technology when all linear parameters of a stone block sample depend on the maximum yield of marketable blocks governed by natural jointing of rocks (Pershin and Ulyakov, 2014, 2015).

Technology used to separate monolith stones and preformed blocks for construction from rocks mass using a diamond rope cutting machine ensuring reduction in labor content, cost and loss (Ismanov, 
2017), as well as enhancing the process production output.

\section{METHODOLOGY}

\subsection{Field Study}

In this study of Dichinama Marble (Lidge Mariam) Quarry Site three field work were used (i.e. Pre-field work, During field work, and After field work).

\subsubsection{Pre-field work}

In this stage of work reviewing of the previous works related to this study especially in dimensional stone Quarrying of Marble occurrence in northern Ethiopia, Tigrai, the factors which affects the quality of Marble, the technologies used to cut the marble squared blocks, the operational method of recovering the standard Squared block size from the rock mass of Marble deposit.

\subsubsection{During field work}

In this step of study observing the Dichinama Marble (Lidge Mariam) site like the topography of the site, the geological discontinuities (such as micro and macro fractures, joints, cavities, foreign materials other than marble), the steps of marble Quarry operational methods, the recoverable percentage, the grading system of the Squared blocks of Marble, and collecting the data of the primary volume cut and the recovered volume.

During the field work a total 135 sample of the primary volume cut and the recovered volume were collected from three-year production time shown (Table 1, Table 2, Table 3) below.

\subsubsection{Post field work}

In this stage interpretating and analysing the collected data and interrelating with the reviewed previous works were done. In this stage the SPSS version 20 was used to show the result Marble Quarry Recovery Rate. 
International Journal of Engineering Applied Sciences and Technology, 2020

Vol. 5, Issue 5, ISSN No. 2455-2143, Pages 166-183

Published Online September 2020 in IJEAST (http://www.ijeast.com)

Table -1 Data of Primary volume cut and Recovered volume from July, 2008 upto June, 2009

Data of Dichinama Marble (Lidge Mariam) Quarry Site

Rose Green and Multicolor Marble

July, 2008 - June, 2009

\begin{tabular}{|c|c|c|c|c|}
\hline S/No & Primary No & Bench & $\begin{array}{c}\text { Primary volume Cut } \\
\left(\mathbf{M}^{\mathbf{3}}\right)\end{array}$ & $\begin{array}{r}\text { Recovered Volume } \\
\left(\mathbf{M}^{3}\right)\end{array}$ \\
\hline 1 & 60 & $1^{\text {st }}$ & 67.20 & 33.92 \\
\hline 2 & 59 & $\mathbf{1}^{\text {st }}$ & 201.71 & 32.56 \\
\hline 3 & 57 & $1^{\text {st }}$ & 50.96 & 31.94 \\
\hline 4 & 58 & $1^{\text {st }}$ & 126.55 & 26.90 \\
\hline 5 & 23 & overburden & 74.52 & 13.94 \\
\hline 6 & 56 & $1^{\text {st }}$ & 160.58 & 70.21 \\
\hline 7 & 22 & overburden & 54.00 & 13.87 \\
\hline 8 & 55 & $1^{\text {st }}$ & 214.27 & 50.87 \\
\hline 9 & 54 & $1^{\text {st }}$ & 100.25 & 9.47 \\
\hline 10 & 53 & $3^{\text {rd }}$ & 85.50 & 35.81 \\
\hline 11 & 20 & overburden & 287.64 & 41.88 \\
\hline 12 & 21 & Overburden & 74.37 & 45.54 \\
\hline 13 & 53 & $1^{\text {st }}$ & 92.40 & 19.56 \\
\hline 14 & 20 & $4^{\text {th }}$ & 37.79 & 6.55 \\
\hline 15 & 21 & $4^{\text {th }}$ & 97.50 & 69.82 \\
\hline 16 & 22 & $4^{\text {th }}$ & 40.95 & 6.09 \\
\hline 17 & 23 & $4^{\text {th }}$ & 75.35 & 73.82 \\
\hline 18 & 55 & $3^{\text {rd }}$ & 144.65 & 27.33 \\
\hline 19 & 24 & $4^{\text {th }}$ & 70.73 & 33.89 \\
\hline 20 & 25 & $4^{\text {th }}$ & 120.00 & 58.79 \\
\hline 21 & 26 & $4^{\text {th }}$ & 148.50 & 101.67 \\
\hline 22 & 27 & $4^{\text {th }}$ & 50.88 & 24.73 \\
\hline 23 & 89 & $2^{\text {nd }}$ & 178.20 & 3.32 \\
\hline 24 & 90 & $2^{\text {nd }}$ & 99.63 & 3.80 \\
\hline 25 & 91 & $2^{\text {nd }}$ & 109.69 & 16.31 \\
\hline 26 & 92 & $2^{\text {nd }}$ & 135.85 & 47.46 \\
\hline 27 & 93 & $2^{\text {nd }}$ & 129.11 & 2.35 \\
\hline 28 & 94 & $2^{\text {nd }}$ & 185.98 & 62.35 \\
\hline 29 & 95 & $2^{\text {nd }}$ & 113.40 & 83.76 \\
\hline 30 & 96 & $2^{\text {nd }}$ & 55.96 & 6.39 \\
\hline 31 & 97 & $2^{\text {nd }}$ & 132.00 & 106.57 \\
\hline 32 & 98 & $2^{\text {nd }}$ & 79.65 & 28.87 \\
\hline 33 & 99 & $2^{\text {nd }}$ & 66.80 & 10.36 \\
\hline 34 & 100 & $2^{\text {nd }}$ & 191.53 & 15.33 \\
\hline 35 & 101 & $2^{\text {nd }}$ & 129.25 & 45.38 \\
\hline 36 & 54 & $3^{\text {rd }}$ & 144.65 & 27.33 \\
\hline 37 & 56 & $3^{\text {rd }}$ & 212.40 & 45.48 \\
\hline 38 & 61 & $1^{\text {st }}$ & 187.60 & 72.80 \\
\hline 39 & 62 & $1^{\text {st }}$ & 134.17 & 80.22 \\
\hline
\end{tabular}


International Journal of Engineering Applied Sciences and Technology, 2020

Vol. 5, Issue 5, ISSN No. 2455-2143, Pages 166-183

Published Online September 2020 in IJEAST (http://www.ijeast.com)

Table -2 Data of Primary volume cut and Recovered volume from July, 2009 upto June, 2010

Data of Dichinama Marble (Lidge Mariam) Quarry Site

Rose Green and Multicolor Marble

July, 2009 - June, 2010

\begin{tabular}{|c|c|c|c|c|}
\hline S/No & Primary No & Bench & $\begin{array}{c}\text { Primary volume Cut } \\
\left(\mathbf{M}^{3}\right)\end{array}$ & $\begin{array}{r}\text { Recovered Volume } \\
\left(\mathbf{M}^{3}\right)\end{array}$ \\
\hline 1 & 102 & $2^{\text {nd }}$ & 124.00 & 90.50 \\
\hline 2 & 103 & $2^{\text {nd }}$ & 159.60 & 69.65 \\
\hline 3 & 105 & $2^{\text {nd }}$ & 151.27 & 64.56 \\
\hline 4 & 104 & $2^{\text {nd }}$ & 118.41 & 8.65 \\
\hline 5 & 106 & $2^{\text {nd }}$ & 114.66 & 47.53 \\
\hline 6 & 107 & $2^{\text {nd }}$ & 196.80 & 104.89 \\
\hline 7 & 108 & $2^{\text {nd }}$ & 79.34 & 28.52 \\
\hline 8 & 109 & $2^{\text {nd }}$ & 140.79 & 75.05 \\
\hline 9 & 57 & $3^{\text {rd }}$ & 124.03 & 19.62 \\
\hline 10 & 58 & $3^{\text {rd }}$ & 212.40 & 45.48 \\
\hline 11 & 59 & $3^{\text {rd }}$ & 188.50 & 97.21 \\
\hline 12 & 60 & $3^{\text {rd }}$ & 173.25 & 122.11 \\
\hline 13 & 61 & $3^{\text {rd }}$ & 66.00 & 0.00 \\
\hline 14 & 62 & $3^{\text {rd }}$ & 297.00 & 0.00 \\
\hline 15 & 63 & $\mathbf{3}^{\text {rd }}$ & 372.00 & 162.41 \\
\hline 16 & 64 & $3^{\text {rd }}$ & 149.49 & 0.00 \\
\hline 17 & 65 & $3^{\text {rd }}$ & 281.19 & 147.37 \\
\hline 18 & 66 & $\mathbf{3}^{\text {rd }}$ & 65.19 & 22.81 \\
\hline 19 & 67 & $3^{\text {rd }}$ & 136.36 & 66.25 \\
\hline 20 & 68 & $3^{\text {rd }}$ & 121.50 & 29.81 \\
\hline 21 & 69 & $3^{\text {rd }}$ & 162.00 & 46.76 \\
\hline 22 & 70 & $3^{\text {rd }}$ & 186.05 & 38.98 \\
\hline 23 & 71 & $3^{\text {rd }}$ & 92.34 & 38.82 \\
\hline 24 & 72 & $3^{\text {rd }}$ & 186.05 & 38.98 \\
\hline 25 & 73 & $\mathbf{3}^{\text {rd }}$ & 92.34 & 38.82 \\
\hline 26 & 28 & $4^{\text {th }}$ & 64.32 & 36.60 \\
\hline 27 & 29 & $4^{\text {th }}$ & 87.81 & 64.37 \\
\hline 28 & 30 & $4^{\text {th }}$ & 52.50 & 39.57 \\
\hline 29 & 31 & $4^{\text {th }}$ & 95.50 & 47.59 \\
\hline 30 & 32 & $4^{\text {th }}$ & 74.49 & 43.53 \\
\hline 31 & 33 & $4^{\text {th }}$ & 41.49 & 34.87 \\
\hline 32 & 34 & $4^{\text {th }}$ & 167.31 & 63.49 \\
\hline 33 & 35 & $4^{\text {th }}$ & 162.00 & 152.46 \\
\hline 34 & 36 & $4^{\text {th }}$ & 170.09 & 91.40 \\
\hline 35 & 37 & $4^{\text {th }}$ & 202.50 & 117.62 \\
\hline 36 & 38 & $4^{\text {th }}$ & 127.50 & 89.71 \\
\hline 37 & 39 & $4^{\text {th }}$ & 91.77 & 28.53 \\
\hline 38 & 40 & $4^{\text {th }}$ & 118.80 & 100.82 \\
\hline 39 & 63 & $1^{\text {st }}$ & 240.00 & 34.92 \\
\hline 40 & 64 & $1^{\text {st }}$ & 264.00 & 81.16 \\
\hline 41 & 65 & $1^{\text {st }}$ & 144.00 & 54.94 \\
\hline 42 & 66 & $\mathrm{~s}^{\mathrm{st}}$ & 176.00 & 20.66 \\
\hline 43 & 67 & $1^{\text {st }}$ & 80.28 & 42.11 \\
\hline 44 & 68 & $1^{\text {st }}$ & 173.88 & 48.58 \\
\hline 45 & 69 & $1^{\text {st }}$ & 195.00 & 42.22 \\
\hline 46 & 70 & $1^{\text {st }}$ & 46.44 & 5.70 \\
\hline 47 & 71 & $1^{\text {st }}$ & 541.00 & 3.52 \\
\hline
\end{tabular}


International Journal of Engineering Applied Sciences and Technology, 2020

Vol. 5, Issue 5, ISSN No. 2455-2143, Pages 166-183

Published Online September 2020 in IJEAST (http://www.ijeast.com)

Table -3 Data of Primary volume cut and Recovered volume from July, 2010 upto June, 2011

Data of Dichinama Marble (Lidge Mariam) Quarry Site

Rose Green and Multicolor Marble

July, 2010 - June, 2011

\begin{tabular}{|c|c|c|c|c|}
\hline S/No & Primary No & Bench & $\begin{array}{c}\text { Primary volume Cut } \\
\left(\mathbf{M}^{3}\right)\end{array}$ & $\begin{array}{r}\text { Recovered Volume } \\
\left(\mathbf{M}^{3}\right)\end{array}$ \\
\hline 1 & 41 & $4^{\text {th }}$ & 137.94 & 22.22 \\
\hline 2 & 42 & $4^{\text {th }}$ & 84.48 & 35.48 \\
\hline 3 & 45 & $4^{\text {th }}$ & 74.62 & 34.01 \\
\hline 4 & 44 & $4^{\text {th }}$ & 23.10 & 0.00 \\
\hline 5 & 43 & $4^{\text {th }}$ & 102.00 & 54.58 \\
\hline 6 & 46 & $4^{\text {th }}$ & 63.00 & 12.28 \\
\hline 7 & 47 & $4^{\text {th }}$ & 178.22 & 37.59 \\
\hline 8 & 48 & $4^{\text {th }}$ & 128.00 & 45.27 \\
\hline 9 & 49 & $4^{\text {th }}$ & 44.50 & 26.19 \\
\hline 10 & 110 & $2^{\text {nd }}$ & 155.00 & 57.13 \\
\hline 11 & 111 & $2^{\text {nd }}$ & 72.00 & 35.58 \\
\hline 12 & 112 & $2^{\text {nd }}$ & 153.00 & 58.23 \\
\hline 13 & 113 & $2^{\text {nd }}$ & 86.00 & 25.83 \\
\hline 14 & 114 & $2^{\text {nd }}$ & 208.00 & 81.00 \\
\hline 15 & 115 & $2^{\text {nd }}$ & 59.22 & 24.13 \\
\hline 16 & 116 & $2^{\text {nd }}$ & 98.40 & 13.70 \\
\hline 17 & 117 & $2^{\text {nd }}$ & 193.30 & 40.52 \\
\hline 18 & 118 & $2^{\text {nd }}$ & 196.35 & 56.45 \\
\hline 19 & 119 & $2^{\text {nd }}$ & 92.40 & 45.65 \\
\hline 20 & 120 & $2^{\text {nd }}$ & 124.74 & 83.40 \\
\hline 21 & 121 & $2^{\text {nd }}$ & 134.64 & 71.78 \\
\hline 22 & 122 & $2^{\text {nd }}$ & 178.20 & 71.43 \\
\hline 23 & 123 & $2^{\text {nd }}$ & 161.70 & 84.78 \\
\hline 24 & 124 & $2^{\text {nd }}$ & 63.36 & 16.18 \\
\hline 25 & 125 & $2^{\text {nd }}$ & 109.94 & 84.68 \\
\hline 26 & 126 & $2^{\text {nd }}$ & 86.60 & 41.94 \\
\hline 27 & 127 & $2^{\text {nd }}$ & 84.00 & 76.12 \\
\hline 28 & 128 & $2^{\text {nd }}$ & 66.00 & 36.00 \\
\hline 29 & 129 & $2^{\text {nd }}$ & 122.00 & 91.00 \\
\hline 30 & 130 & $2^{\text {nd }}$ & 282.72 & 87.00 \\
\hline 31 & 131 & $2^{\text {nd }}$ & 34.00 & 0.00 \\
\hline 32 & 132 & $2^{\text {nd }}$ & 82.17 & 50.64 \\
\hline 33 & 72 & $1^{\text {st }}$ & 57.75 & 13.46 \\
\hline 34 & 73 & $1^{\text {st }}$ & 89.40 & 47.73 \\
\hline 35 & 74 & $1^{\text {st }}$ & 69.00 & 38.36 \\
\hline 36 & 75 & $1^{\text {st }}$ & 63.36 & 28.33 \\
\hline 37 & 76 & $1^{\text {st }}$ & 115.50 & 40.00 \\
\hline 38 & 77 & $1^{\text {st }}$ & 69.30 & 12.30 \\
\hline 39 & 78 & $1^{\text {st }}$ & 178.93 & 52.70 \\
\hline 40 & 79 & $1^{\text {st }}$ & 110.00 & 25.36 \\
\hline 41 & 80 & $1^{\text {st }}$ & 153.00 & 60.50 \\
\hline 42 & 81 & $1^{\text {st }}$ & 92.40 & 32.78 \\
\hline 43 & 82 & $1^{\text {st }}$ & 39.60 & 14.68 \\
\hline 44 & 83 & $1^{\text {st }}$ & 195.36 & 42.22 \\
\hline 45 & 84 & $1^{\text {st }}$ & 216.00 & $\mathbf{5 8 . 0 0}$ \\
\hline 46 & 85 & $1^{\text {st }}$ & 31.20 & 0.00 \\
\hline 47 & 86 & $\mathbf{1}^{\text {st }}$ & 193.08 & 31.85 \\
\hline 48 & 87 & $1^{\text {st }}$ & 36.00 & 20.00 \\
\hline 49 & 88 & $1^{\text {st }}$ & 112.50 & 16.32 \\
\hline
\end{tabular}




\section{MARBLE QUARRY OPERATION}

4.1 Steps of Marble Quarrying

In Dichinama Marble (Lidge Mariam) Quarry Site the operational work is carried out by the help of machineries and man power the steps are as follows:

\subsubsection{Overburden Removal}

In the study area of Dichinama Quarry Marble (Lidge Mariam) site the first step in quarry mining which includes the removal of unwanted materials like plants, soil, weathered rocks, and other materials cleared from the deposit (mineralized area) using the loader or using diamond wire cutting machines it depends on if the material is soft such as soil and plants loader is preferable unless diamond wire cutting machines to uncover the Marble which is economically important.

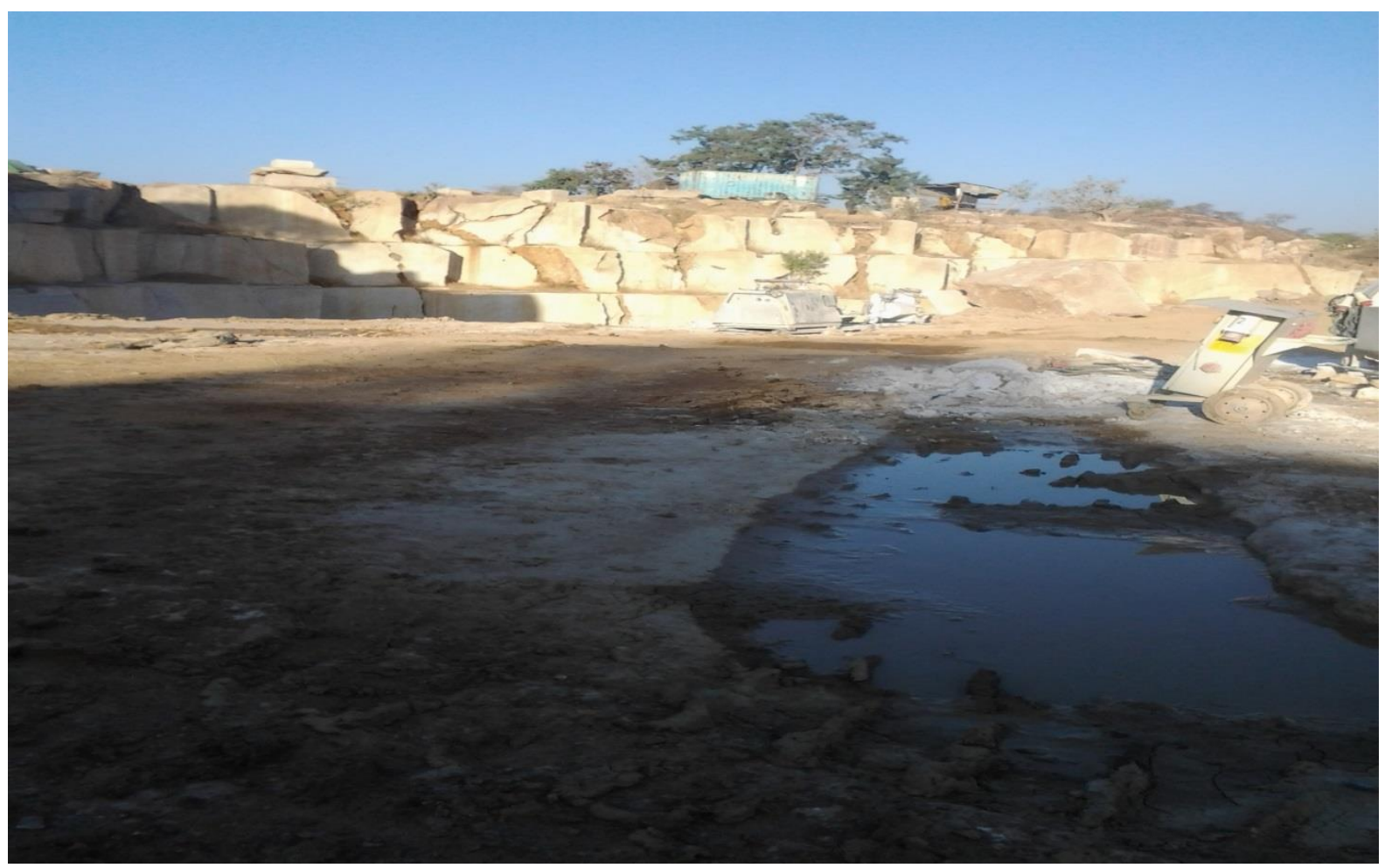

Fig. 2. Dichinama Marble (Lidge Mariam) Quarry Site

\subsubsection{Identifying the Quarry Front}

In the study area opening the first face accomplishing by forming a cut across the quarry width orienting the cut in opposite direction to the dip line of the of the Marble deposit.

\subsubsection{Vertical Drilling}

In Dichinama marble quarry the labors wash the deposit to identify the direction of the spot line on the marble surface area to be visible for drilling. After finding the spot line drill vertical according to the height of the bench. To accomplish the work in a successful manner they drill wisely by the help of pneumatic driller machine.

\subsubsection{Horizontal Drilling}

After drilling vertical, drilling of two horizontal holes by measuring the dimensions and following the alignment of tensioning by using the rope to connect the vertical drill hole and the horizontal they want to drill are in line. After tensioning meets the target, starting horizontal drilling by using the horizontal driller machine. After finishing the drilling of two holes and connecting with the vertical holes it forms the shape of V-pattern.

\subsubsection{Horizontal Cutting}

After connecting the two horizontal drill holes, they closed the vertical drill hole by cloth and chips to prevent escaping of air and to pass the diamond wire using pneumatic action through the horizontal holes. Then, they connect the diamond wire using steel jointer by presser and the next step is horizontal cutting by using Diamond wire mounted on the fly 
wheel of Benetti or Pelegrini machines that have the capacity to cut the primary cuttings.

\subsubsection{Vertical Cutting}

In vertical cutting, two cutting processes are performed. To do the first cutting process, sending the rope through the vertical drill hole then after by the horizontal drill hole send an elongated steel to catch and tight the rope.

After that connect the diamond wire by steel or copper jointer using presser the after mounting to the fly wheel of either Benetti or Pelegrini machines. The same is true for the second vertical cutting process. Here we use Benetti or Pelegrini machines.

\subsubsection{Slicing}

After cutting the primary block, the next step is slicing by measuring 1.10 meters interval which meets the standard block sizes. After that they splitting to their block size must be suitable for the capacity of the loader to push and pull the block by using bull machine with combination of jacking followed by hydro bag to detach and split the sliced block from the primary cuttings. After the sliced block is detached from the primary cut, the loader operator supplies soil to support the failing down sliced block to protect from breakage and prepares the loader for falling down the sliced block using the rake.

\subsubsection{Block Squaring}

After falling down the sliced block, the workers washes it and the geologist come to find the spot line

Table -4 The standard blocks size of Dichinama (Lidge Mariam) Site during Block Squaring

\begin{tabular}{|l|l|l|}
\hline Parameters & Gang saw & Block cutter \\
\hline Length & $2.61 \mathrm{~m}-3 \mathrm{~m}$ & $0.8 \mathrm{~m}-2.1 \mathrm{~m}$ \\
\hline Width & $1.3 \mathrm{~m}-1.8 \mathrm{~m}$ & $2.5 \mathrm{~m}$ \\
\hline Height & $1.16 \mathrm{~m}-2 \mathrm{~m}$ & $1.16 \mathrm{~m}$ \\
\hline
\end{tabular}

Table -5 Grading system of Dichinama Marble (Lidge Mariam) Quarry Site of Squared Blocks

\begin{tabular}{|l|r|}
\hline Block Grades & Classifying Criteria's \\
\hline Grade A & $>\quad$ Good presence of spot line, almost parallel line $\left(\mathbf{1 8 0}^{\circ}\right)$. \\
& $>\quad$ Not presence of any fracture. \\
& $>\quad$ Aot presence of any impurities. \\
& $>\quad$ It should be uniform in color. \\
& $>\quad$ The recovery of the block must be $>65 \%$. \\
\hline Grade B & $>\quad$ Less presence of fracture. \\
& $>\quad$ Not presence of schist. \\
& $>\quad$ Recovery of the block is $25-65 \%$. \\
\hline Grade C & $>\quad$ Fractures occur less in the diagonal of the squared block. \\
& $>\quad$ Less presence of schist. \\
& $>\quad$ Not well squared. \\
&
\end{tabular}




\begin{tabular}{|l|ll|}
\hline Rejected block & $>$ & Contains a greater number of fractures in diagonal of the block \\
& $>$ & High number of schists with wrongly squared block. \\
\hline
\end{tabular}

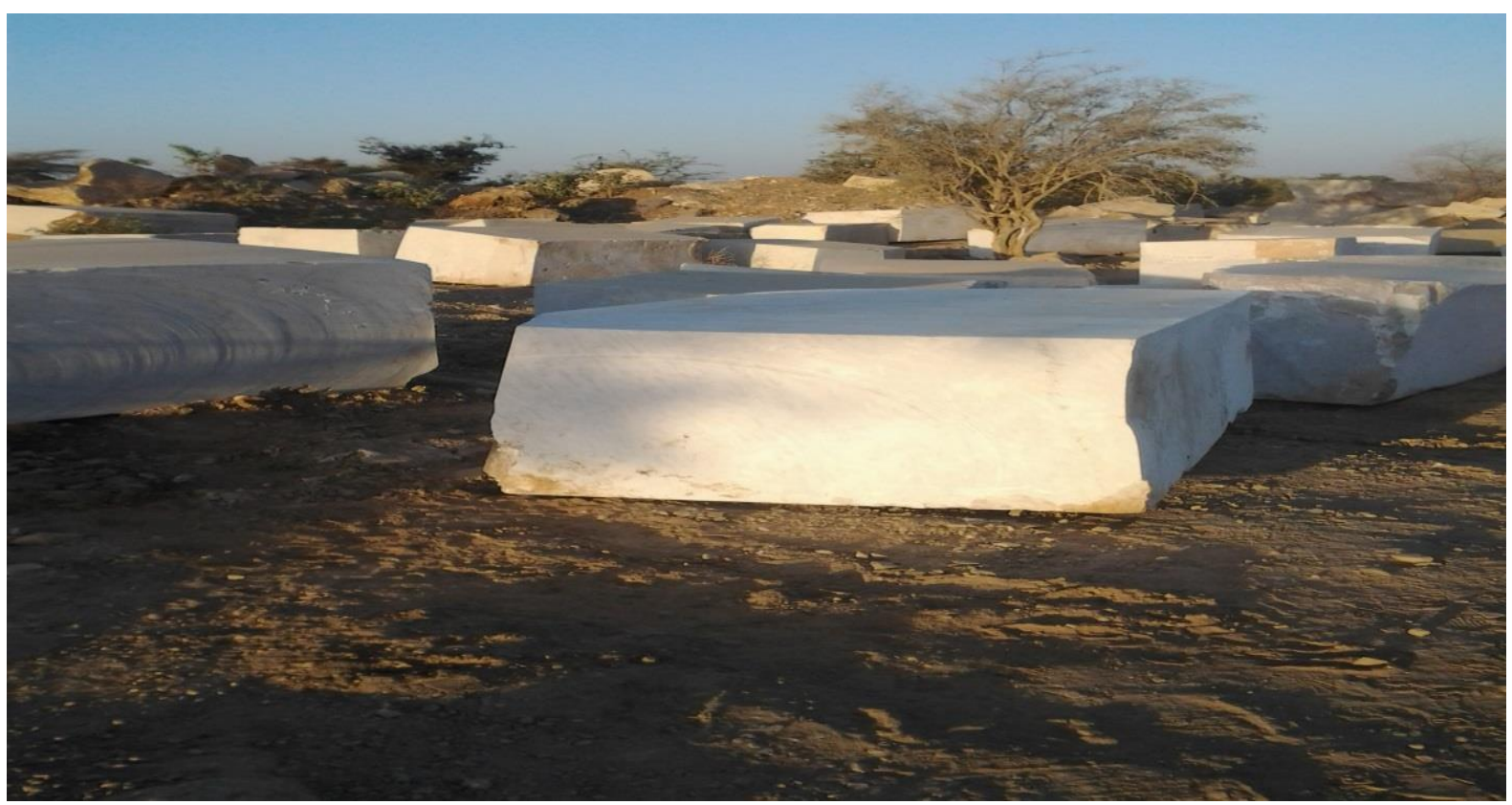

Fig. 3. Stock Yard of Dichinama Marble (Lidge Mariam) Quarry Site

\section{RESULT AND DISCUSSION}

\subsection{Result}

In this study the result of the Recovery Rate (percentage) is calculated in bench wise and a statistical software (i.e. SPSS) version 20 was using to show the last result of the recovery rate of Dichinama Marble (Lidge Mariam) Quarry site. The Quarry site of Dichinama (Lidge Mariam) has four benches and the recovery rate of one bench is different to another bench. Besides from the normal benches there is another recover percentage of Squared block of marble from the overburden during cutting the unwanted material and weathered part of the Marble from the active working site of Dichinama (Lidge Mariam) Quarry Site.

The Formula used in this study to Calculate the recovery rate (percentage) from Dichinama Marble (Lidge Mariam) Quarry site is as following;

Recovery Rate $=\frac{\text { Primary cuttings X }}{\text { Recovered Volume }}$
Where, the primary cuttings are in volume of cubic meter or $\left(\mathrm{M}^{3}\right)$ and the recovered volume is also in $\left(\mathrm{M}^{3}\right)$

In this study 135 sample primary cuttings are taken to study the recoverable percentage of squared blocks of Marble in the Dichinama (Lidge Mariam) Quarry site.

These samples are taken from each benches of the open pit Quarry of the Dichinama Marble (Lidge Mariam) site. The data is collected from the site and from office of the geology and quality control service. The sample of the primary cuttings are 36 from first bench, 44 from second bench, 21 from third bench, 30 from fourth bench, and 4 from the overburden cuttings.

The result of the recovery rate (percentage) of the study area of the Dichinama Marble (Lidge Mariam) Quarry site for first bench, second bench, third bench, fourth bench, overburden, and the total of the site are shown in the table $6,7,8,9,10$ and also the total Recovery rate of Dichinama Marble (Lidge Mariam) Quarry site is shown in table 11 below. 
International Journal of Engineering Applied Sciences and Technology, 2020

Vol. 5, Issue 5, ISSN No. 2455-2143, Pages 166-183

Published Online September 2020 in IJEAST (http://www.ijeast.com)

Table -6 Recovery Rate of Dichinama Marble Quarry first Bench July, 2008 - June, 2011

\begin{tabular}{|c|c|c|c|c|c|}
\hline \multicolumn{6}{|c|}{ Recovery Rate of Dichinama Marble (Lidge Mariam) Quarry Site } \\
\hline \multicolumn{6}{|c|}{ Rose Green and Multicolor Marble } \\
\hline \multicolumn{6}{|c|}{ July, 2008 - June, 2011} \\
\hline S/No & Primary No & Bench & Primary volume Cut $\left(\mathbf{M}^{3}\right)$ & $\begin{array}{c}\text { Recovered Volume } \\
\left(\mathbf{M}^{3}\right)\end{array}$ & Recovery Rate (\%) \\
\hline 1 & 53 & $1^{\text {st }}$ & 92.40 & 19.56 & 21.17 \\
\hline 2 & 54 & $\mathbf{1}^{\text {st }}$ & 100.25 & 9.47 & 9.45 \\
\hline 3 & 55 & $\mathbf{1}^{\text {st }}$ & 214.27 & $\mathbf{5 0 . 8 7}$ & 23.74 \\
\hline 4 & 56 & $1^{\text {st }}$ & 160.58 & 70.21 & 43.72 \\
\hline 5 & 57 & $1^{\text {st }}$ & 50.96 & 31.94 & 62.68 \\
\hline 6 & 58 & $1^{\text {st }}$ & 126.55 & 26.90 & 21.26 \\
\hline 7 & 59 & $1^{\text {st }}$ & 201.71 & 32.56 & 16.14 \\
\hline 8 & 60 & $1^{\text {st }}$ & 67.20 & 33.92 & 50.47 \\
\hline 9 & 61 & $1^{\text {st }}$ & 187.60 & 72.80 & 38.81 \\
\hline 10 & 62 & $1^{\text {st }}$ & 134.17 & 80.22 & 59.79 \\
\hline 11 & 63 & $1^{\text {st }}$ & 240.00 & 34.92 & 14.55 \\
\hline 12 & 64 & $1^{\text {st }}$ & 264.00 & 81.16 & 30.74 \\
\hline 13 & 65 & $1^{\text {st }}$ & 144.00 & 54.94 & 38.15 \\
\hline 14 & 66 & $1^{\text {st }}$ & 176.00 & 20.66 & 11.74 \\
\hline 15 & 67 & $1^{\text {st }}$ & 80.28 & 42.11 & 52.45 \\
\hline 16 & 68 & $1^{\text {st }}$ & 173.88 & 48.58 & 27.94 \\
\hline 17 & 69 & $1^{\text {st }}$ & 195.00 & 42.22 & 21.65 \\
\hline 18 & 70 & $1^{\text {st }}$ & 46.44 & 5.70 & 12.27 \\
\hline 19 & 71 & $1^{\text {st }}$ & 541.00 & 3.52 & 0.65 \\
\hline 20 & 72 & $1^{\text {st }}$ & $\mathbf{5 7 . 7 5}$ & 13.46 & 23.31 \\
\hline 21 & 73 & $1^{\text {st }}$ & 89.40 & 47.73 & 53.39 \\
\hline 22 & 74 & $1^{\text {st }}$ & 69.00 & 38.36 & 55.59 \\
\hline 23 & 75 & $1^{\text {st }}$ & 63.36 & 28.33 & 44.71 \\
\hline 24 & 76 & $1^{\text {st }}$ & 115.50 & 40.00 & 34.63 \\
\hline 25 & 77 & $1^{\text {st }}$ & 69.30 & 12.30 & 17.75 \\
\hline 26 & 78 & $1^{\text {st }}$ & 178.93 & 52.70 & 29.45 \\
\hline 27 & 79 & $1^{\text {st }}$ & 110.00 & 25.36 & 23.05 \\
\hline 28 & 80 & $1^{\text {st }}$ & 153.00 & 60.50 & 39.54 \\
\hline 29 & 81 & $1^{\text {st }}$ & 92.40 & 32.78 & 35.48 \\
\hline 30 & 82 & $1^{\text {st }}$ & 39.60 & 14.68 & 37.07 \\
\hline 31 & 83 & $1^{\text {st }}$ & 195.36 & 42.22 & 21.61 \\
\hline 32 & 84 & $1^{\text {st }}$ & 216.00 & 58.00 & 26.85 \\
\hline 33 & 85 & $1^{\text {st }}$ & 31.20 & 0.00 & 0.00 \\
\hline 34 & 86 & $\mathbf{1}^{\text {st }}$ & 193.08 & 31.85 & 16.49 \\
\hline 35 & 87 & $1^{\text {st }}$ & 36.00 & 20.00 & 55.55 \\
\hline 36 & 88 & $1^{\text {st }}$ & 112.50 & 16.32 & 14.51 \\
\hline \multicolumn{3}{|c|}{ Total } & 5018.67 & $\mathbf{1 2 9 6 . 8 5}$ & 25.84 \\
\hline
\end{tabular}


International Journal of Engineering Applied Sciences and Technology, 2020

Vol. 5, Issue 5, ISSN No. 2455-2143, Pages 166-183

Published Online September 2020 in IJEAST (http://www.ijeast.com)

Table -7 Recovery Rate of Dichinama Marble Quarry second Bench July, 2008 - June, 2011

\begin{tabular}{|c|c|c|c|c|c|}
\hline \multicolumn{6}{|c|}{ Recovery Rate of Dichinama Marble (Lidge Mariam) Quarry Site } \\
\hline \multicolumn{6}{|c|}{ Rose Green and Multicolor Marble } \\
\hline \multicolumn{6}{|c|}{ July, 2008 - June, 2011} \\
\hline S/No & Primary No & Bench & Primary volume Cut $\left(\mathbf{M}^{\mathbf{3}}\right)$ & $\begin{array}{c}\text { Recovered Volume } \\
\left(\mathbf{M}^{3}\right)\end{array}$ & Recovery Rate (\%) \\
\hline 1 & 89 & $2^{\text {nd }}$ & 178.20 & 3.32 & 1.86 \\
\hline 2 & 90 & $2^{\text {nd }}$ & 99.63 & 3.80 & 3.81 \\
\hline 3 & 91 & $2^{\text {nd }}$ & 109.69 & 16.31 & 14.87 \\
\hline 4 & 92 & $2^{\text {nd }}$ & 135.85 & 47.46 & 34.94 \\
\hline 5 & 93 & $2^{\text {nd }}$ & 129.11 & 2.35 & 1.82 \\
\hline 6 & 94 & $2^{\text {nd }}$ & 185.98 & 62.35 & 33.53 \\
\hline 7 & 95 & $2^{\text {nd }}$ & 113.40 & 83.76 & 73.86 \\
\hline 8 & 96 & $2^{\text {nd }}$ & 55.96 & 6.39 & 11.42 \\
\hline 9 & 97 & $2^{\text {nd }}$ & 132.00 & 106.57 & 80.73 \\
\hline 10 & 98 & $2^{\text {nd }}$ & 79.65 & 28.87 & 36.25 \\
\hline 11 & 99 & $2^{\text {nd }}$ & 66.80 & 10.36 & 15.51 \\
\hline 12 & 100 & $2^{\text {nd }}$ & 191.53 & 15.33 & 8.00 \\
\hline 13 & 101 & $2^{\text {nd }}$ & 129.25 & 45.38 & 35.11 \\
\hline 14 & 102 & $2^{\text {nd }}$ & 124.00 & 90.50 & 72.98 \\
\hline 15 & 103 & $2^{\text {nd }}$ & 159.60 & 69.65 & 43.64 \\
\hline 16 & 104 & $2^{\text {nd }}$ & 118.41 & 8.65 & 7.31 \\
\hline 17 & 105 & $2^{\text {nd }}$ & 151.27 & 64.56 & 42.68 \\
\hline 18 & 106 & $2^{\text {nd }}$ & 114.66 & 47.53 & 41.45 \\
\hline 19 & 107 & $2^{\text {nd }}$ & 196.80 & 104.89 & 53.29 \\
\hline 20 & 108 & $2^{\text {nd }}$ & 79.34 & 28.52 & 35.94 \\
\hline 21 & 109 & $2^{\text {nd }}$ & 140.79 & 75.05 & 53.31 \\
\hline 22 & 110 & $2^{\text {nd }}$ & 155.00 & 57.13 & 36.86 \\
\hline 23 & 111 & $2^{\text {nd }}$ & 72.00 & 35.58 & 49.42 \\
\hline 24 & 112 & $2^{\text {nd }}$ & 153.00 & 58.23 & 38.06 \\
\hline 25 & 113 & $2^{\text {nd }}$ & 86.00 & 25.83 & 30.03 \\
\hline 26 & 114 & $2^{\text {nd }}$ & 208.00 & 81.00 & 38.94 \\
\hline 27 & 115 & $2^{\text {nd }}$ & 59.22 & 24.13 & 40.75 \\
\hline 28 & 116 & $2^{\text {nd }}$ & 98.40 & 13.70 & 13.92 \\
\hline 29 & 117 & $2^{\text {nd }}$ & 193.30 & 40.52 & 20.96 \\
\hline 30 & 118 & $2^{\text {nd }}$ & 196.35 & 56.45 & 28.75 \\
\hline 31 & 119 & $2^{\text {nd }}$ & 92.40 & 45.65 & 49.40 \\
\hline 32 & 120 & $2^{\text {nd }}$ & 124.74 & 83.40 & 66.86 \\
\hline 33 & 121 & $2^{\text {nd }}$ & 134.64 & 71.78 & 53.31 \\
\hline 34 & 122 & $2^{\text {nd }}$ & 178.20 & 71.43 & 40.08 \\
\hline 35 & 123 & $2^{\text {nd }}$ & 161.70 & 84.78 & 52.43 \\
\hline 36 & 124 & $2^{\text {nd }}$ & 63.36 & 16.18 & 25.54 \\
\hline 37 & 125 & $2^{\text {nd }}$ & 109.94 & 84.68 & 77.02 \\
\hline 38 & 126 & $2^{\text {nd }}$ & 86.60 & 41.94 & 48.43 \\
\hline 39 & 127 & $2^{\text {nd }}$ & 84.00 & 76.12 & 90.62 \\
\hline 40 & 128 & $2^{\text {nd }}$ & 66.00 & 36.00 & 54.55 \\
\hline 41 & 129 & $2^{\text {nd }}$ & 122.00 & 91.00 & 74.59 \\
\hline 42 & 130 & $2^{\text {nd }}$ & 282.72 & 87.00 & 30.77 \\
\hline 43 & 131 & $2^{\text {nd }}$ & 34.00 & 0.00 & 0.00 \\
\hline 44 & 132 & $2^{\text {nd }}$ & 82.17 & 50.64 & 61.63 \\
\hline \multicolumn{3}{|c|}{ Total } & 5535.66 & 2154.77 & 38.93 \\
\hline
\end{tabular}


International Journal of Engineering Applied Sciences and Technology, 2020

Vol. 5, Issue 5, ISSN No. 2455-2143, Pages 166-183

Published Online September 2020 in IJEAST (http://www.ijeast.com)

Table -8 Recovery Rate of Dichinama Marble Quarry third Bench July, 2008 - June, 2011

\begin{tabular}{|c|c|c|c|c|c|}
\hline \multicolumn{6}{|c|}{ Recovery Rate of Dichinama Marble (Lidge Mariam) Quarry Site } \\
\hline \multicolumn{6}{|c|}{$\begin{array}{c}\text { Rose Green and Multicolor Marble } \\
\text { July, 2008 - June, } 2011\end{array}$} \\
\hline S/No & Primary No & Bench & Primary volume Cut $\left(\mathbf{M}^{3}\right)$ & $\begin{array}{c}\text { Recovered Volume } \\
\left(\mathbf{M}^{3}\right)\end{array}$ & Recovery Rate (\%) \\
\hline 1 & 53 & $3^{\text {rd }}$ & $\mathbf{8 5 . 5 0}$ & 35.81 & 41.88 \\
\hline 2 & 54 & $3^{\text {rd }}$ & 144.65 & 27.33 & 18.89 \\
\hline 3 & 55 & $3^{\text {rd }}$ & 124.03 & 19.62 & 15.82 \\
\hline 4 & 56 & $3^{\text {rd }}$ & 212.40 & 45.48 & 21.41 \\
\hline 5 & 57 & $3^{\text {rd }}$ & 188.50 & 97.21 & 51.57 \\
\hline 6 & 58 & $3^{\text {rd }}$ & 173.25 & 122.11 & 70.48 \\
\hline 7 & 59 & $3^{\text {rd }}$ & 66.00 & 0.00 & 0.00 \\
\hline 8 & 60 & $3^{\text {rd }}$ & 297.00 & 0.00 & 0.00 \\
\hline 9 & 61 & $3^{\text {rd }}$ & 372.00 & 162.41 & 43.66 \\
\hline 10 & 62 & $3^{\text {rd }}$ & 138.06 & 36.45 & 26.40 \\
\hline 11 & 63 & $3^{\text {rd }}$ & 98.94 & 63.27 & 63.95 \\
\hline 12 & 64 & $3^{\text {rd }}$ & 149.49 & 0.00 & 0.00 \\
\hline 13 & 65 & $3^{\text {rd }}$ & 281.19 & 147.37 & 52.41 \\
\hline 14 & 66 & $3^{\text {rd }}$ & 65.19 & 22.81 & 34.99 \\
\hline 15 & 67 & $3^{\text {rd }}$ & 136.36 & 66.25 & 48.58 \\
\hline 16 & 68 & $3^{\text {rd }}$ & 121.50 & 29.81 & 24.53 \\
\hline 17 & 69 & $3^{\text {rd }}$ & 162.00 & 46.76 & 28.86 \\
\hline 18 & $\mathbf{7 0}$ & $3^{\text {rd }}$ & 186.05 & 38.98 & 20.95 \\
\hline 19 & 71 & $3^{\text {rd }}$ & 92.34 & 38.82 & 42.04 \\
\hline 20 & 72 & $3^{\text {rd }}$ & 186.05 & 38.98 & 20.95 \\
\hline 21 & 73 & $3^{\text {rd }}$ & 92.34 & 38.82 & 42.04 \\
\hline \multicolumn{3}{|c|}{ Total } & 3372.84 & 1078.29 & 31.97 \\
\hline
\end{tabular}


International Journal of Engineering Applied Sciences and Technology, 2020

Vol. 5, Issue 5, ISSN No. 2455-2143, Pages 166-183

Published Online September 2020 in IJEAST (http://www.ijeast.com)

Table -9 Recovery Rate of Dichinama Marble fourth Bench July, 2008 - June, 2011

\begin{tabular}{|c|c|c|c|c|c|}
\hline \multicolumn{6}{|c|}{ Recovery Rate of Dichinama Marble (Lidge Mariam) Site } \\
\hline \multicolumn{6}{|c|}{ Rose Green and Multicolor Marble } \\
\hline \multicolumn{6}{|c|}{ July, 2008 - June, 2011} \\
\hline S/No & Primary No & Bench & Primary volume Cut $\left(\mathbf{M}^{\mathbf{3}}\right)$ & $\begin{array}{c}\text { Recovered Volume } \\
\left(\mathbf{M}^{3}\right)\end{array}$ & Recovery Rate (\%) \\
\hline 1 & 20 & $4^{\text {th }}$ & 37.79 & 6.55 & $\mathbf{1 7 . 3 3}$ \\
\hline 2 & 21 & $4^{\text {th }}$ & 97.50 & 69.82 & 71.61 \\
\hline 3 & 22 & $4^{\text {th }}$ & 40.95 & 6.09 & 14.87 \\
\hline 4 & 23 & $4^{\text {th }}$ & 75.35 & $\mathbf{7 3 . 8 2}$ & 97.97 \\
\hline 5 & 24 & $4^{\text {th }}$ & 70.73 & 33.89 & 47.91 \\
\hline 6 & 25 & $4^{\text {th }}$ & 120.00 & 58.79 & 48.99 \\
\hline 7 & 26 & $4^{\text {th }}$ & 148.50 & 101.67 & 68.46 \\
\hline 8 & 27 & $4^{\text {th }}$ & 50.88 & 24.73 & 48.60 \\
\hline 9 & 28 & $4^{\text {th }}$ & 64.32 & 36.60 & 56.90 \\
\hline 10 & 29 & $4^{\text {th }}$ & 87.81 & 64.37 & 73.31 \\
\hline 11 & 30 & $4^{\text {th }}$ & 52.50 & 39.57 & 75.37 \\
\hline 12 & 31 & $4^{\text {th }}$ & 95.50 & 47.59 & 49.83 \\
\hline 13 & 32 & $4^{\text {th }}$ & 74.49 & 43.53 & 58.44 \\
\hline 14 & 33 & $4^{\text {th }}$ & 41.49 & 34.87 & 84.04 \\
\hline 15 & 34 & $4^{\text {th }}$ & 167.31 & 63.49 & 37.95 \\
\hline 16 & 35 & $4^{\text {th }}$ & 162.00 & 152.46 & 94.11 \\
\hline 17 & 36 & $4^{\text {th }}$ & 170.09 & 91.40 & 53.74 \\
\hline 18 & 37 & $4^{\text {th }}$ & 202.50 & 117.62 & 58.08 \\
\hline 19 & 38 & $4^{\text {th }}$ & 127.50 & 89.71 & 70.36 \\
\hline 20 & 39 & $4^{\text {th }}$ & 91.77 & 28.53 & 31.09 \\
\hline 21 & 40 & $4^{\text {th }}$ & 118.80 & 100.82 & 84.87 \\
\hline 22 & 41 & $4^{\text {th }}$ & 137.94 & 22.22 & 16.11 \\
\hline 23 & 42 & $4^{\text {th }}$ & 84.48 & 35.48 & 41.99 \\
\hline 24 & 43 & $4^{\text {th }}$ & 102.00 & 54.58 & 53.51 \\
\hline 25 & 44 & $4^{\text {th }}$ & 23.10 & 0.00 & 0.00 \\
\hline 26 & 45 & $4^{\text {th }}$ & 74.62 & 34.01 & 45.58 \\
\hline 27 & 46 & $4^{\text {th }}$ & 63.00 & 12.28 & 19.49 \\
\hline 28 & 47 & $4^{\text {th }}$ & 178.22 & 37.59 & 21.09 \\
\hline 29 & 48 & $4^{\text {th }}$ & 128.00 & 45.27 & 35.37 \\
\hline 30 & 49 & $4^{\text {th }}$ & 44.50 & 26.19 & 58.85 \\
\hline \multicolumn{3}{|c|}{ Total } & 2933.64 & 1553.54 & 52.96 \\
\hline
\end{tabular}

Table -10 Recovery Rate of Dichinama Marble Quarry from Overburden July, 2008 - June, 2011

\begin{tabular}{|c|c|c|c|c|c|}
\hline \multicolumn{6}{|c|}{ Recovery Rate of Dichinama Marble (Lidge Mariam) Quarry Site } \\
\hline \multicolumn{6}{|c|}{ Rose Green and Multicolor Marble } \\
\hline \multicolumn{6}{|c|}{ July, 2008 - June, 2011} \\
\hline S/No & Primary No & Bench & $\begin{array}{c}\text { Primary volume Cut } \\
\left(\mathbf{M}^{3}\right)\end{array}$ & $\begin{array}{c}\text { Recovered Volume } \\
\left(\mathbf{M}^{\mathbf{3}}\right)\end{array}$ & Recovery Rate (\%) \\
\hline 1 & 20 & Overburden & 287.64 & 41.88 & 14.56 \\
\hline 2 & 21 & Overburden & 74.37 & 45.54 & 61.23 \\
\hline 3 & 22 & Overburden & 54.00 & 13.87 & 25.69 \\
\hline 4 & 23 & Overburden & 74.52 & 13.94 & 18.71 \\
\hline \multicolumn{3}{|c|}{ Total } & 490.53 & 115.23 & 23.49 \\
\hline & & & \multicolumn{3}{|c|}{ Total Recovery Rate $=\mathbf{2 3 . 4 9 \%}$} \\
\hline
\end{tabular}


International Journal of Engineering Applied Sciences and Technology, 2020

Vol. 5, Issue 5, ISSN No. 2455-2143, Pages 166-183

Published Online September 2020 in IJEAST (http://www.ijeast.com)

Table -11 Total Recovery Rate of Dichinama Marble (Lidge Mariam) Quarry Site

\begin{tabular}{|c|c|c|}
\hline \multicolumn{3}{|c|}{ Recovery Rate Data of Dichinama Marble (Lidge Mariam) Quarry Site } \\
\hline \multicolumn{3}{|c|}{ Rose Green and Multicolor Marble } \\
\hline \multicolumn{3}{|c|}{$2008-2011$} \\
\hline $\begin{array}{l}\text { Total Volume Cut from } 135 \text { primaries } \\
\qquad(36+44+21+4) \text { in }\left(\mathrm{M}^{3}\right)\end{array}$ & $\begin{array}{l}\text { Total Volume Recovered from } 135 \text { Primaries } \\
\qquad(36+44+21+4) \text { in }\left(M^{3}\right)\end{array}$ & Recovery Rate (\%) \\
\hline \multirow{2}{*}{\multicolumn{2}{|c|}{$\begin{array}{c}6198.68 \\
\text { Total Recovery Rate }=35.72 \%\end{array}$}} & 35.72 \\
\hline & & \\
\hline
\end{tabular}

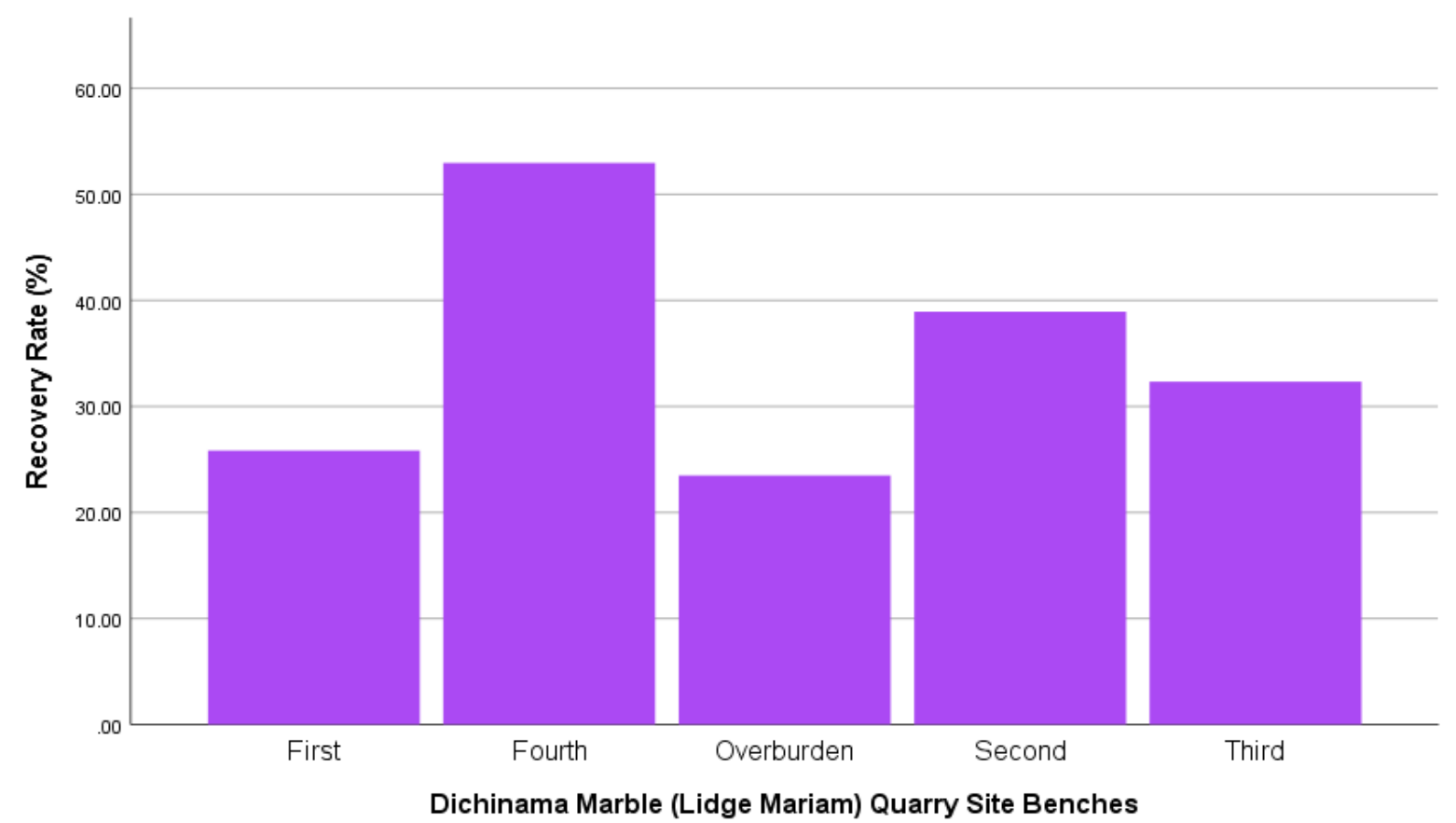

Fig. 4. Recovery Rate of Dichinama Marble Quarry Site from July, 2008 upto June, 2011

\subsection{Discussion}

Dichinama Marble (Lidge Mariam) Quarry site have different recovery rate in the four benches and overburden cuttings in the first bench $25.84 \%$, second bench $38.93 \%$, third bench $31.97 \%$, fourth bench $52.96 \%$, and from the overburden $23.49 \%$. So, from this there is a great difference among first bench, fourth bench, and overburden. The main reason for this is the geological discontinuities and found in the marble quarry. According Ashmole and Motloung, (2008) It is obvious that Marble is affected by geological structures same is true in the marble quarry of Dichnama (Quarry site) especially the third bench is highly affected by cavity.
During the overburden volume cuttings of $490.53 \mathrm{M}^{3}$ and recovered volume of $115.23 \mathrm{M}^{3}$ the recoverable percentage is $23.49 \%$ which is very low because of the weathered part and the formation of cavities during the reaction of the composition of marble that is calcite with the surface water, plant roots which forms mudstones in the marble.

In the first bench a total of $5018.67 \mathrm{M}^{3}$ primary volume cuttings and $1296.85 \mathrm{M}^{3}$ recovered volume from 36 primaries respectively, the recovery rate is $25.84 \%$ and the rejected volume is $3721.82 \mathrm{M}^{3}$ which accounts $74.16 \%$ this is because of the joints and plant roots which highly affected the quality of the marble to have a standardized squared block thus the recoverable percentage is low when compared to second, third and fourth bench. 


\section{International Journal of Engineering Applied Sciences and Technology, 2020 Vol. 5, Issue 5, ISSN No. 2455-2143, Pages 166-183 \\ Published Online September 2020 in IJEAST (http://www.ijeast.com)}

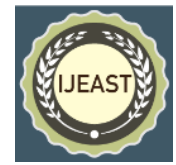

In the second, third and fourth bench the amount of rejected volume are $3380.89 \mathrm{M}^{3}, 2,294.55 \mathrm{M}^{3}, 1,380.1$ $\mathrm{M}^{3}$ in terms of percentage $61.07 \%, 68.03 \%, 47.04 \%$ respectively. The third bench has a cavity in northern part its bench face which affected the quality of the marble and it is difficult some time in recovering a squared block from that bench. In the fourth bench there is a high percentage of recovery compared with other benches in site because of the presence of the geological discontinuities found there is less and the effect is less also it is found in deeper location compared to other benches.

In this study the total Recovery Rate of the Dichinama (Lidge Mariam) Quarry Site has 35.72\% from a total $17351.34 \mathrm{M}^{3}$ of primary volume cuttings and a total $6198.68 \mathrm{M}^{3}$ recovered volume in other words the total cut from 135 primaries is the sum of the four benches primary cuttings and from the overburden cuttings $(5018.67+5535.66+3372.84+2933.64+490.53=$ $\left.17351.34 \mathrm{M}^{3}\right)$ and the total volume recovered $(1296.85+2154.77+1078.29+1553.54+115.23=$ $\left.6198.68 \mathrm{M}^{3}\right)$.

The result of Recovery Rate of the Dichinama Marble (Lidge Mariam) Quarry site from benches and overburden cuttings using SPSS version 20 is clearly shown in figure 4 above.

From 135 samples of primary cuttings and $64.28 \%$ which accounts in volume of $11,152.66 \mathrm{M}^{3}$ were rejects the geological discontinuities play a great role in the low recovery rate of the marble quarrying in the site there are discontinuities such as microfractures, joints, cavities, and mudstones which is found in the site especially in the northern and northwestern part marble quarry. Apart from the geological structures the other problem found in the study are is the operational method of opening the Marble Quarry and the cuttings of the primary in $\mathrm{V}$ - shape which leads to low recovery percentage.

\section{CONCLUSION}

One of the biggest companies which produces marble is Saba Dimensional Stone PLC at Dichinama marble (Lidge Mariam) Quarry site. Dichnama Marble (Lidge Mariam) Quarry Site is located in northern Ethiopia Tigray region Northwestern zone $35 \mathrm{~km}$ far from the Sheraro town to the residence camp and $38 \mathrm{~km}$ to the active site Lidge Mariam. The local geology of the areas is Meta sediments exposures younger Sheraro formation. The marble belts of lidge Mariam marble deposits are covered with Meta sediments and dipping to the NW at $60^{\circ}$ to the vertical and the marble belt trends $\mathrm{N} 40^{\circ} \mathrm{E}$. In Dichinama Marble (Lidge Mariam) Quarry site the percentage of recoverable volume is low affected by geological discontinuities found in the site such as micro and macro fractures, joints, cavities, and mudstones and also other foreign materials other than marble.

In this study 135 sample primary cuttings are taken to study the recoverable percentage of squared blocks of Marble in the Dichinama (Lidge Mariam) Quarry site. These samples are taken from each benches of the open pit Quarry of the Dichinama Marble (Lidge Mariam) site. The data is collected from the site and from office of the geology and quality control service. The sample of the primary cuttings are 36 from first bench, 44 from second bench, 21 from third bench, 30 from fourth bench, and 4 from the overburden cuttings.

Dichinama Marble (Lidge Mariam) Quarry site have different recovery rate in the four benches and from overburden cuttings in the first bench $25.84 \%$, second bench $38.93 \%$, third bench $31.97 \%$, fourth bench $52.96 \%$, and from the overburden $23.49 \%$.

In this study the total Recovery Rate of the Dichinama (Lidge Mariam) Quarry Site has $35.72 \%$ from a total $17351.34 \mathrm{M}^{3}$ of primary volume cuttings and a total $6198.68 \mathrm{M}^{3}$ recovered volume from 135 samples of primary cuttings and $64.28 \%$ which accounts in volume of $11,152.66 \mathrm{M}^{3}$ were rejects the geological discontinuities play a great role in the low recovery rate of the marble quarrying and apart from the geological structures the other problem found in the study are is the operational method of opening the Marble Quarry and the cuttings of the primary in Vshape which leads to low recovery percentage.

\section{ACKNOWLEDGMENT}

I would like to express my immense gratitude towards following people, for helping in the completion of the article on " Determining the Recovery Rate of Dichinama Marble (Lidge Mariam) Quarry Site at Northwestern Zone, Tigrai, Ethiopia". Mr. Yewuhalashet Fissha and Mr. Angesom Gebretsadik for their advice and motivation starting from the beginning to the completion of this article.

\section{REFERENCE}

[1] Ashmole, I. and Motloung, M. (2008). Dimension stone: the latest trends in exploration and production technology Greenstone Marble and Granite ( Pty ) Ltd Finstone ( SA ) ( Pty ) Ltd, The Southern African Institute of Mining and Metallurgy, Surface Mi(2008), pp. 35-70. Available at: http://www.saimm.co.za/Conferences/SurfaceMining 2008/035-070_Ashmole.pdf.

[2] Ismanov, M. M. (2017). Technology of dimension stone cutting, Journal of Mining Science, 53(2), pp. 


\section{International Journal of Engineering Applied Sciences and Technology, 2020 Vol. 5, Issue 5, ISSN No. 2455-2143, Pages 166-183 \\ Published Online September 2020 in IJEAST (http://www.ijeast.com)}

305-310. doi: 10.1134/S1062739117022163.

[3] Melka, H. (2010). The Extractive Industry in Ethiopia and Efforts Made to Join \& Implement the Extractive Industries Transparency Initiative (EITI) in Ethiopia. Presentation to the Public Dialogue on Governance and Transparency in $\sim . .$.

[4] Ozcelik, Y. (1999). Investigation of the working conditions of diamond wire cutting machines in marble industry. PhD Thesis, Hacettepe University, Ankara (in Turkish).

[5] Özçelik, Y. (2003). Multivariate statistical analysis of the wear on diamond beads in the cutting of andesitic rocks, in Key Engineering Materials, pp. 118-130.

[6] Özçelik, Y. (2005). Effect of mineralogical and petrographical properties of marble on cutting by diamond wire, CIM Bulletin, 98(1085), pp. 1-6.

[7] Pershin, G. D. and Ulyakov, M. S. (2014). Analysis of the effect of wire saw operation mode on stone cutting cost, Journal of Mining Science, 50(2), pp. 310-318. doi: 10.1134/S1062739114020148.

[8] Pershin, G. D. and Ulyakov, M. S. (2015). Enhanced dimension stone production in quarries with complex natural jointing, Journal of Mining Science, 51(2), pp. 330-334. doi: $10.1134 / \mathrm{S} 1062739115020167$.

[9] Polat, E. (2002). Investigation of the effect of textural properties on marble cutting with diamond wire, Hacettepe University.

[10] Rajpurohit, S. S. et al. (2018). Influence of physico-mechanical properties of Indian dimension stones on cutting rate of diamond wire saw, Arabian Journal of Geosciences. Arabian Journal of Geosciences, 11(18). doi: 10.1007/s12517-018-39138.

[11] Servet, D. et al. (2014). Variation of vertical and horizontal drilling rates depending on some rock properties in the marble quarries, International Journal of Mining Science and Technology. China University of Mining \& Technology, 24(2), pp. 269273. doi: 10.1016/j.ijmst.2014.01.020.

[12] Tadesse, S., Milesi, J. P. and Deschamps, Y. (2003). Geology and mineral potential of Ethiopia: A note on geology and mineral map of Ethiopia, Journal of African Earth Sciences. doi: 10.1016/S08995362(03)00048-4.

[13] Yarahmadi, R. et al. (2018). Discontinuity modelling and rock block geometry identification to optimize production in dimension stone quarries, Engineering Geology. Elsevier, 232(October 2017), pp. 22-33. doi: 10.1016/j.enggeo.2017.11.006.

[14] Yarahmadi, R. et al. (2019). A new quality factor for the building stone industry: a case study of stone blocks, slabs, and tiles, Bulletin of Engineering Geology and the Environment. Springer Berlin Heidelberg, 78(1), pp. 533-542. doi: 10.1007/s10064017-1040-5. 